\title{
Oceanography
}

CITATION

Kappel, E.S. 2014. Mary Johrde and the birth of the UNOLS fleet. Oceanography 27(4)

supplement:23, http://dx.doi.org/10.5670/oceanog.2014.109.

DOI

http://dx.doi.org/10.5670/oceanog.2014.109

COPYRIGHT

This article has been published in Women in Oceanography, a supplement to Oceanography, Volume 27, Number 4. Oceanography is the quarterly journal of The Oceanography Society. Copyright 2014 by The Oceanography Society. All rights reserved.

USAGE

Permission is granted to copy this article for use in teaching and research. Republication, systematic reproduction, or collective redistribution of any portion of this article by photocopy machine, reposting, or other means is permitted only with the approval of The Oceanography Society. Send all correspondence to: info@tos.org or The Oceanography Society, PO Box 1931, Rockville, MD 20849-1931, USA. 


\section{SIDEBAR. Mary Johrde and the Birth of the UNOLS Fleet}

By Ellen S. Kappel

Most US ocean scientists today take ship scheduling, coordinated via UNOLS (University-National Oceanographic Laboratory System), for granted. They are too young to remember a time when oceanographic institutions such as Scripps Institution of Oceanography, Woods Hole Oceanographic Institution, and Lamont Geological Observatory (now the Lamont-Doherty Earth Observatory) ran their own ships and scheduled research cruises, with little attention or concern for operational efficiency or the needs of the broader community. It was unusual for a scientist to sail on another institution's vessel, especially as a chief scientist. All of that changed in 1971, in large part due to the inexorable Mary Johrde of the National Science Foundation (NSF), who stood up to a group of notvery-happy lab directors who saw UNOLS as a way of losing control over their ships.

Mary Johrde, a petite biologist-not an oceanographer by training, but with extensive NSF experience in the field of facilities operations-was articulate and smart as whip with strong convictions that the existing system could not endure. She was given the responsibility within NSF for creating a new National Oceanographic Laboratory System (NOLS). In January 1971, she put together the "NOLS Planning Document: Short Version," which laid out NSF's vision for management of the academic research fleet, including NSF's role (see Byrne and Dinsmore, 2000, for a more complete and detailed history of the origins of UNOLS). NSF had several reasons for putting forth this plan, including the rising cost of ship operations, declining Office of Naval Research funding, the need for greater accountability, and pressure to accommodate a broader community on the ships. Mary Johrde was strong in her defense of the plan, and stood her ground against the lab directors. "Eight or so lab directors on one side; Mary Johrde on the other-the odds were almost even" (Byrne and Dinsmore, 2000, p. 111). In the end, a compromise was made, and later that year, UNOLS was born.

Mary Johrde, along with Feenan Jennings, went on to lead the formation of the Division of Ocean Sciences in the mid1970s. By then, Mary had been at NSF almost 20 years (she arrived there in November 1958). She started her NSF career as a program assistant to the newly established Specialized
Facilities Program in the Biological and Medical Sciences Division (BMS), one of two original NSF divisions (the other was Mathematics, Physics, and Engineering [MPE]). In 1965 she became an assistant program director in Earth science when the Earth and Atmospheric Science sections were split off from MPE and put in the new Division of Environmental Sciences (DES). In that role, Mary attempted to "establish a single NSF Advisory Panel for Ship Operations, block funding for ships, and guidelines for evaluating and managing this very essential support for the community" (Johrde, 2000, p. 94). In a next reorganization of NSF programs in 1968, NSF made her program director for the DES Oceanographic Facilities Program, where she made her mark in the early UNOLS years. In 1971, NSF created the Office for Oceanographic Facilities and Support to implement management support for the NOLS concept, which Mary headed until 1981 when she retired from NSF after a long and very distinguished career.

ACKNOWLEDGEMENTS. I would like to thank Sandra Toye for her invaluable input on this essay and for introducing me to Mary Johdre at a recent memorial honoring Bruce Malfait. I am also grateful to Sandy Shor and Larry Clark for their reviews and comments, which improved this essay. Meagan Thompson generously helped to verify some dates.

\section{REFERENCES}

Johrde, M. Ocean science at the National Science Foundation: Early evolution. Pp. 93-95 in 50 Years of Ocean Discovery: National Science Foundation 1950-2000. Ocean Studies Board, National Research Council, National Academy Press, Washington, DC

Byrne, J.V., and R.P. Dinsmore. 2000. Two years of turbulence leading to a quarter century of cooperation: The birth of UNOLS. Pp. 107-115 in 50 Years of Ocean Discovery: National Science Foundation 1950-2000. Ocean Studies Board, National Research Council, National Academy Press, Washington, DC.

AUTHOR. Ellen S. Kappel (ekappel@geo-prose.com) is President, Geosciences Professional Services Inc., Bethesda, MD, USA. 